Ekonomia - Wroclaw Economic Review 26/3 (2020)

Acta Universitatis Wratislaviensis

No 4008

https://doi.org/10.19195/2658-1310.26.3.2

Iwona Czerska

ORCID: 0000-0002-9680-6695

Uniwersytet Ekonomiczny we Wroclawiu

iwona.czerska@ue.wroc.pl

Angelika Trojanowska

ORCID: 0000-0002-3546-138X

Uniwersytet Ekonomiczny we Wrocławiu

angelika.trojanowska1991@gmail.com

Tetiana Korpak

ORCID: 0000-0003-2209-3642

Uniwersytet Ekonomiczny we Wrocławiu

tetiana.korpak@gmail.com

\title{
Medycyna stylu życia jako prozdrowotny trend współczesnego prosumenta
}

Artykuł nadesłany: 4.05.2020; artykuł zaakceptowany: 21.09.2020

Kody klasyfikacji JEL: C10, D11, I12, I31, M31

Keywords: lifestyle medicine, prosumer, EBM

\section{Abstract \\ Lifestyle medicine as a pro-health trend of the modern prosumer}

The aim of this study is to present the profile of the modern prosumer and analyze their behavior on the health services market in the context of the latest health-promoting trend - lifestyle medicine. The patient's participation in medical diagnostics was discussed. Attention was paid to the reasons for transformation of medical systems, among others due to changes in the patient's needs. The theoretical aspects of lifestyle medicine, including evidence-based medicine (EBM), were discussed. Finally, an analysis of the lifestyle of Polish consumers was made based on the results of own study. Less than $20 \%$ of respondents are familiar with the term "lifestyle medicine". Most respondents identify this term with a healthy lifestyle. The respondents' declarations show that the modern consumer leads a healthy lifestyle, regularly engaging in sports and eating properly balanced meals. As an informed consumer, he or she reads the labels on the packaging and considers 
each purchase very carefully. He or she is also vulnerable to advertising and other marketing tools, and is aware of this. Nearly $61 \%$ of respondents do not know the term "prosumer". For other people, a prosumer is the modern consumer who consciously and actively makes choices, is involved in co-creating the product and takes part in its promotion.

\section{Wstęp}

W dobie współczesnej gospodarki, zdeterminowanej z jednej strony intensywnym rozwojem nowoczesnych technologii informacyjno-komunikacyjnych, z drugiej zaś - starzeniem się społeczeństwa, zachowanie konsumenta na rynku się zmienia, koncentrując na dokonywaniu świadomych wyborów i większej dbałości o własne zdrowie. Wyzwania, jakie niosą cyfryzacja i postęp techniczny, wymuszają dostosowywanie się społeczeństwa do wymagań transformacji przemysłowej.

Współczesny konsument określany jest mianem konsumenta digitalnego, doskonale zaadaptowanego do obecnej rzeczywistości rynkowej, korzystającego z nowych rozwiązań mobilnych, również w kontekście troski o zdrowie. Zmieniają się jego potrzeby, preferencje, oczekiwania oraz sposób podejmowania decyzji (Krzepicka, 2016). Konsument nowej ery działa wielokanałowo, sprawnie realizując proces zakupowy zgodnie ze strategią omnichannel. Jest przy tym niezależny, autentyczny, krytyczny, analityczny, ale też niecierpliwy i zmienny (Krzepicka, 2016). Takie zachowanie konsumenta znajduje swoje odzwierciedlenie w służbie zdrowia w kontekście cyfryzacji sektora zdrowotnego.

W opracowaniu dokonano przeglądu literatury przedmiotu i stron internetowych prezentujących informacje o nowej dziedzinie medycznej, jaką jest medycyna stylu życia. Ponadto przeprowadzono analizę statystyczną wyników badania własnego. Wyznaczono podstawowe statystyki opisowe, takie jak: średnią arytmetyczną, odchylenie standardowe, medianę, dominantę, kwartyl pierwszy i trzeci, klasyczny współczynnik zmienności. Wyniki zaprezentowano w postaci tabelarycznej, jak też sporządzono wykres i diagram.

\section{Współczesny prosument na rynku usług zdrowotnych}

\subsection{Sylwetka i potrzeby konsumenta XXI wieku}

Termin ,prosument” po raz pierwszy został wprowadzony w książce The Third Wave przez A. Tofflera (1980). Jest on połączeniem wyrazów „producent” lub „profesjonalista” oraz „konsument”. Odbiorca końcowy zaangażowany w promowanie oraz współtworzenie produktów, usług bądź danej marki nazywany jest prosumentem (Prosument, 2019). Coraz częściej współcześni konsumenci chcą 
mieć wpływ na proces kształtowania danego rynku, nabywając doświadczenia z poszczególnymi produktami lub usługami. A. Toffler (1997) podzielił prosumenta na dwie główne kategorie:

— prosumenta zaangażowanego w czynności prosumpcji pierwszej fali: oczekującego głównie korzyści ekonomicznych;

— prosumenta zaangażowanego w czynności prosumpcji trzeciej fali: poza czynnikami ekonomicznymi swoją uwagę skupia na aspektach społecznych oraz ekologicznych.

Kim zatem jest konsument usług zdrowotnych? Świadczeniobiorcami w rozumieniu ustawy o zakładach opieki zdrowotnej są pacjenci mający prawo do korzystania z powszechnego ubezpieczenia zdrowotnego, ale z punktu widzenia zarządzających zakładami opieki zdrowotnej (zoz) za biorców oferowanych świadczeń uważać należy wszystkich, którzy decydują się na pozyskanie usług (świadczenia zdrowotnego) w danym zozie lub praktyce lekarskiej/pielęgniarskiej (również osoby korzystające ze świadczeń zdrowotnych poza systemem powszechnego ubezpieczenia zdrowotnego, czyli nabywających świadczenia za opłatą) (Kautsch, 2010, 68).

Świadom swoich potrzeb konsument, dostępnymi mu środkami, jest w stanie przez różnego rodzaju aplikacje kontrolować między innymi: swoją aktywność fizyczną, dietę, zdrowie. Według raportu Technologia w stużbie społeczeństwu. Czy Polacy zostana społeczeństwem 5.0? 97\% ankietowanych uważa, że nowe technologie są potrzebne, $90 \%$ zaś dostrzega ich podstawową rolę w rozwoju polskiej gospodarki (Fundacja Digital Poland, 2019, 6). Aplikacje muszą o sobie przypominać, walczyć o uwagę, sięgać do psychologii zachowań w celu zwrócenia i zatrzymania uwagi pacjenta. Grać na emocjach i potrzebach, odpowiadać na nie, optymalizować procesy zdrowotne, lecz także stawiać pacjenta $\mathrm{w}$ centrum procesu terapeutycznego. Działania te mają za zadanie zmianę pojedynczych prozdrowotnych zachowań w stały nawyk, w których telefon jest narzędziem motywacyjnym, źródłem dyscypliny oraz przypomnieniem pomagającym w utrzymaniu kondycji. „Technologia tworzona w mądry sposób nie musi nachalnie walczyć o naszą uwagę, bo sami chętnie z niej korzystamy” (Technologie, 2019).

\subsection{Udział pacjenta $w$ diagnostyce medycznej}

Pacjent ma coraz większe oczekiwania wobec systemu opieki medycznej oraz swojego zdrowia. Chce zdrowo się odżywiać, żyć w zdrowym środowisku, przywiązuje większą wagę do świadomej profilaktyki. Według Janusza Czapińskiego, wieloletniego kierownika projektu „Diagnoza społeczna”, zdrowie jest dla Polaków najważniejsze. Zgodnie z wynikami owego projektu w latach 2000-2015 niezmiennie we wszystkich pomiarach największy odsetek rodaków (około 70\%) do trzech kardynalnych wartości zaliczał zdrowie (Czapiński, 2019, 8). W związ$\mathrm{ku}$ z tym pacjent potrzebuje zdrowej oraz zbilansowanej diety, a to zapewniają 
mu nieliczne aplikacje możliwe do pobrania na każdy telefon, promujące zdrową żywność oraz oferujące porady dietetyczne. Rozwiązania technologiczne możliwe do zainstalowania na smartfonach dają też rozwiązania z zakresu poprawy aktywności sportowej. Interaktywne narzędzia są pomocą nie tylko dla pacjentów, lecz także dla lekarzy, wspierają bowiem procesy diagnostyki i leczenia, pozwalają na szybki dostęp do szukanej informacji, skracając czas przeznaczony na szukanie danych pozostawionych na przykład w papierowej formie. Ważnymi czynnikami są transparentność aplikacji opartych na wiedzy naukowej oraz propozycja technologii opartej na wartościach dla konsumenta.

Usługi medyczne mają sprostać wyzwaniom, które stawia przed nimi prosument. Jest on bowiem coraz bardziej świadomy swojego stanu zdrowia oraz usług z zakresu świadczeń medycznych oferowanych na rynku. Znajomość wspólnych oraz specyficznych cech jego potrzeb jest jednym z elementów zarządzania, który dąży do zaspokajania oczekiwań odbiorców oraz będzie skutkował zadowoleniem pacjenta. Opinie oraz satysfakcja pacjentów często determinują sukces placówki (Nowak-Starz et al., 2018, 239), dlatego niezmiernie ważnym elementem życia jednostki medycznej jest ciągłe szukanie odpowiedzi na istotne dla pacjenta potrzeby oraz wartości.

Wychodząc naprzeciw oczekiwaniom prosumentów, jednostki medyczne powinny w znaczący sposób przygotować się do zmian, albowiem proces ten jest przedsięwzięciem wymagającym ciągłego rozwoju, ingerującym zarówno w sposób pracy, procedury, jak i przyzwyczajenia pracowników. Sukces podmiotów w zarządzaniu zmianą zależy w blisko $80 \%$ od umiejętności zarządzania zmianą (czyli głównie lidera czy menedżera), natomiast tylko w 20\% od technologii (Cyfryzacja, 2019). Należy pamiętać, że rozwiązania informatyczne unowocześniające strukturę dotychczasowych działań zdrowotnych powinny być ukierunkowane na potrzeby pacjenta oraz przekazane mu w odpowiedni, dostosowany do jego oczekiwań sposób. To kolejne zadanie dla pracowników jednostek medycznych oraz osób zarządzających personelem (Aleksandrowicz, 2019).

Usługi medyczne wraz z całym procesem ich świadczenia to z jednej strony pacjent $\mathrm{i}$ jego indywidualne potrzeby oraz oczekiwania, zaś z drugiej strony personel medyczny. Personel ten odgrywa kluczową rolę w budowaniu trwałej relacji między usługodawcą a usługobiorcą. Kształtowanie prawidłowych relacji z pacjentami wpływa na cały proces usługowy, w tym również na ostateczną satysfakcję klienta/pacjenta. (Nowak-Starz et al., 2018, 239)

W wypadku profilaktyki zdrowotnej niezwykle ważne jest przełamanie dotychczasowych barier przed stosowaniem nowoczesnych technologii w medycynie.

W celu ulepszenia procesów medycznych oraz większej satysfakcji pacjenta bardzo ważne jest sprawne oraz świadome wdrożenie rozwiązań związanych z dokumentacją medyczną. Wymóg jednolitej formy prowadzenia dokumentacji medycznej oraz spójna podstawa są niezbędnymi elementami zarządzania procesem leczenia pacjenta. Integralność systemów oraz dokumentacji może przynieść maksymalny efekt wszystkim interesariuszom. 
Rozwiązania z zakresu e-zdrowia umożliwiają optymalne wykorzystanie dostępnych struktur i środków. Zapewniają komunikację z pacjentem, ułatwiają codzienną pracę, oszczędzając czas pacjenta oraz personelu medycznego. Mają znaczący wpływ na udoskonalenie procesów oraz lepszą identyfikację problemów i potrzeb pacjenta. Wzmacniają rolę pacjenta w jego diagnostyce, dając tym samym możliwość lepszej obsługi i diagnostyki. Telewizyty, rejestracja online, podręczna apteczka, historia chorób umożliwiająca gromadzenie oraz udostępnianie danych niezbędnych z punktu medycznego, sprawdzanie dostępności leków w aptekach — to tylko nieliczne rozwiązania z zakresu e-zdrowia mogące pomóc w leczeniu i monitorowaniu stanu zdrowia chorych (Gogola, 2019).

Reasumując, udoskonalenie procesów wewnętrznych i zewnętrznych powiązanych z pełnieniem świadczeń zdrowotnych powinno rekomendować świadome uczestnictwo pacjenta w procesach związanych $\mathrm{z}$ jego leczeniem. Zabieg ten może zadziałać również jako element marketingowy, reklamując jednostkę medyczną jako odpowiadającą na potrzeby pacjenta.

\subsection{Transformacja systemów medycznych na skutek zmian potrzeb klienta-pacjenta}

Pacjent jako najważniejszy i ostateczny beneficjent systemu zdrowotnego wymaga zindywidualizowanego podejścia w kontekście zmian jego potrzeb i oczekiwań. Ewolucja systemów opieki zdrowotnej w kierunku systemu pacjentocentrycznego jest powodowana wieloma czynnikami, do których można zaliczyć:

1. większą świadomość pacjentów na temat własnego zdrowia;

2. wzrost wymagań pacjentów w stosunku do opieki zdrowotnej;

3. zmiany potrzeb i oczekiwań konsumentów usług medycznych;

4. polepszenie komunikacji w relacji lekarz-pacjent oraz pacjent-personel medyczny;

5. realny wpływ pacjenta na proces terapeutyczny;

6. wzrost satysfakcji pacjentów ze świadczonych usług.

Podejmowanie decyzji w relacji lekarz-pacjent zmieniało się historycznie i było uzależnione od konkretnego modelu relacji. W tabeli 1 zaprezentowano zestawienie modeli relacji lekarz-pacjent w kontekście aspektów związanych z procesem leczenia się. Ważnym czynnikiem, który definiuje działania w procesie leczenia, jest orientacja na chorobę lub na pacjenta. W modelach analizowana jest postawa lekarza i pacjenta, od których zależy rola lekarza i poziom aktywności pacjenta, niezbędne dla skutecznego wypracowania wspólnych rozwiązań. 
Tabela 1. Zestawienie modeli relacji lekarz-pacjent

\begin{tabular}{|c|c|c|c|c|c|}
\hline Model & $\begin{array}{c}\text { Przedmiot } \\
\text { terapii }\end{array}$ & $\begin{array}{l}\text { Postawa } \\
\text { lekarza }\end{array}$ & $\begin{array}{l}\text { Postawa } \\
\text { pacjenta }\end{array}$ & Rola lekarza & Aktywność pacjenta \\
\hline Parsonsa & choroba & $\begin{array}{l}\text { dominu- } \\
\text { jąca }\end{array}$ & bierna & $\begin{array}{l}\text { autorytatywne ustalanie } \\
\text { i prowadzenie leczenia }\end{array}$ & $\begin{array}{l}\text { pełna gotowość do } \\
\text { podporządkowania się } \\
\text { wymogom leczenia }\end{array}$ \\
\hline $\begin{array}{l}\text { Szasza } \\
\text { i Hollen- } \\
\text { dra }\end{array}$ & choroba & $\begin{array}{l}\text { dominu- } \\
\text { jąca }\end{array}$ & $\begin{array}{l}\text { bierna/ } \\
\text { aktywna }\end{array}$ & $\begin{array}{l}\text { kierowanie/współdzia- } \\
\text { łanie/partnerstwo }\end{array}$ & $\begin{array}{c}\text { posłuszne poddanie } \\
\text { się leczeniu/współpra- } \\
\text { ca w terapii/analiza } \\
\text { sposobów leczenia/de- } \\
\text { cydowanie i ponoszenie } \\
\text { współodpowiedzialno- } \\
\text { ści za leczenie }\end{array}$ \\
\hline $\begin{array}{c}\text { oparty } \\
\text { na teorii } \\
\text { konfliktu }\end{array}$ & choroba & $\begin{array}{l}\text { dominu- } \\
\text { jąca }\end{array}$ & $\begin{array}{c}\text { roszcze- } \\
\text { niowa }\end{array}$ & $\begin{array}{l}\text { nadmierna kontrola } \\
\text { dostępu do świadczeń } \\
\text { medycznych; fawo- } \\
\text { ryzowanie bogatych } \\
\text { pacjentów; zachowanie } \\
\text { wiedzy dla siebie }\end{array}$ & $\begin{array}{l}\text { chęć odzyskania } \\
\text { zdrowia }\end{array}$ \\
\hline $\begin{array}{l}\text { oparty na } \\
\text { ideologii } \\
\text { konsume- } \\
\text { ryzmu }\end{array}$ & pacjent & $\begin{array}{c}\text { part- } \\
\text { nerska, } \\
\text { doradcza }\end{array}$ & aktywna & $\begin{array}{l}\text { partner, doradca, współ- } \\
\text { decydent }\end{array}$ & $\begin{array}{l}\text { aktywne zdobywanie } \\
\text { wiedzy; świadomy } \\
\text { wybór alternatywnych } \\
\text { form pomocy; ocena } \\
\text { rezultatów terapii }\end{array}$ \\
\hline $\begin{array}{c}\text { oparty na } \\
\text { promocji } \\
\text { zdrowia }\end{array}$ & pacjent & $\begin{array}{l}\text { wspie- } \\
\text { rająca, } \\
\text { doradcza }\end{array}$ & aktywna & $\begin{array}{c}\text { terapeuta, promotor } \\
\text { zdrowia }\end{array}$ & $\begin{array}{c}\text { odpowiedzialność za } \\
\text { swoje zdrowie; prowa- } \\
\text { dzenie właściwego stylu } \\
\text { życia }\end{array}$ \\
\hline $\begin{array}{l}\text { informa- } \\
\text { cyjny }\end{array}$ & pacjent & ekspercka & aktywna & $\begin{array}{l}\text { ekspert od dostar- } \\
\text { czanych informacji, } \\
\text { specjalista }\end{array}$ & $\begin{array}{c}\text { podejmowanie decyzji } \\
\text { na podstawie uzyska- } \\
\text { nych informacji od } \\
\text { lekarza-eksperta }\end{array}$ \\
\hline $\begin{array}{l}\text { interpre- } \\
\text { tacyjny }\end{array}$ & pacjent & doradcza & aktywna & $\begin{array}{l}\text { doradca, interpretator, } \\
\text { edukator }\end{array}$ & $\begin{array}{l}\text { podejmowanie kom- } \\
\text { petentnych decyzji na } \\
\text { podstawie dostarczo- } \\
\text { nych informacji }\end{array}$ \\
\hline $\begin{array}{l}\text { delibera- } \\
\text { cyjny }\end{array}$ & pacjent & $\begin{array}{l}\text { otwarta, } \\
\text { komuni- } \\
\text { katywna, } \\
\text { współpra- } \\
\text { cująca }\end{array}$ & aktywna & $\begin{array}{l}\text { współpraca i prowadze- } \\
\text { nie dialogu z pacjentem } \\
\text { w przyjemnej atmo- } \\
\text { sferze }\end{array}$ & $\begin{array}{c}\text { podejmowanie decyzji } \\
\text { o sposobie leczenia } \\
\text { w atmosferze dialogu } \\
\text { i współpracy }\end{array}$ \\
\hline
\end{tabular}

Źródło: Czerska, 2016, 39. 
Model skoncentrowany na pacjencie, na jego potrzebach i oczekiwaniach, wymaga pełnego obustronnego zaangażowania (lekarza i pacjenta), otwartości w dyskusji oraz wspólnej, symultanicznej wymiany informacji. Uważa się, że taki sposób komunikacji wpływa na poprawę zdrowia emocjonalnego pacjenta i cały proces terapeutyczny (Łukowski et al., 2018, 233). Według Markusa Siegera, prezesa Polpharmy, ewolucja w kierunku modelu pacjentocentrycznego jest absolutnie podstawowa w kontekście wydolności systemów opieki zdrowotnej. Do tego należy dodać niezbędne wsparcie pacjentów w prowadzeniu przez nich zdrowego stylu życia (Pacjent, 2019).

Sprawny sposób komunikacji w relacji pacjent-lekarz-rodzina determinuje ewolucję systemu ochrony zdrowia, ale nie można pominąć faktu cyfrowej transformacji sektora zdrowotnego. Współczesny prosument oczekuje usług cyfrowych wspierających go w różnych działaniach, ułatwiających mu codzienne funkcjonowanie, ale także pomagających w zachowaniu zdrowia. Odpowiedzią na to zapotrzebowanie jest technologia blockchain, mogąca mieć wiele zastosowań w systemie healthcare (Pacjent, 2019):

1. umożliwienie bezpiecznego przetwarzania i współdzielenia danych medycznych pacjentów;

2. optymalizację łańcucha dostaw i ograniczenie nielegalnego obrotu lekami;

3. poprawę skuteczności badań klinicznych poprzez eliminację manipulacji danymi;

4. zwiększenie efektywności przez eliminację zbędnej biurokracji i pośredników w płatnościach i rozliczeniach.

Wdrażane rozwiązania informatyczne powinny skupiać się na korzyściach dla pacjenta, aktywizować go i włączać do procesu opieki (O cyfrowej transformacji, 2018). Poza tym powinny brać pod uwagę oczekiwania młodszych pacjentów, którzy traktują rozwiązania cyfrowe jako codzienność. Pragną oni bowiem głównie za pośrednictwem smartfonu zapłacić za usługę oraz zarejestrować się na wizytę. Młody konsument usług zdrowotnych oczekuje od systemów informatycznych pomocy w podejmowaniu decyzji i minimalizacji pojawiających się przy tej okazji ryzyk (e-Zdrowie, 2018).

Cyfryzacja opieki zdrowotnej jest strategicznym działaniem odpowiadającym na rosnące potrzeby i wymagania społeczeństwa. W swoich działaniach digitalizacja procesów medycznych pozwoli na bardziej efektywne finansowanie i łatwiejszy dostęp do kadry medycznej, a w konsekwencji zwiększy zaufanie świadczeniobiorców oraz poprawi wizerunek firmy.

Zdaniem ekspertów cyfryzacji w ochronie zdrowia najistotniejsze trendy 2020 roku ukierunkowane na potrzeby pacjentów będą związane z (Innowacje, 2019):

1. refundacją zakupu zdrowotnych aplikacji mobilnych „leki nowej generacji”. Największym wyzwaniem tego procesu będzie stworzenie systemu weryfikacji dla aplikacji mobilnych, który powinien zapewniać lekarzom prowadzącym prawidłowość i wiarygodność danych; 
2. wzbudzaniem zaufania do stosowania technologii cyfrowego zdrowia;

3. współtworzeniem rozwiązań razem z użytkownikami końcowymi, czyli zaangażowaniem pacjenta $\mathrm{w}$ budowę procesów odpowiadających na ich potrzeby. Wspólna praca personelu medycznego, specjalistów od rozwiązań technologicznych oraz pacjentów może przynieść efektywne rozwiązania systemowe;

4. integracją dotąd niepowiązanych z ochroną zdrowia branży;

5. rozbudową oraz dalszymi pracami nad koncepcją „cyfrowego bliźniaka” — repliką każdego człowieka przeniesioną do wirtualnego świata (indywidualny zbiór danych o każdej jednostce, w tym danych zdrowotnych).

Reasumując, transformacja systemu zdrowotnego, w tym rewolucja cyfrowa, powinna odpowiadać oczekiwaniom pacjentów oraz świadczeniodawców, jak również ograniczyć sztucznie narastające kolejki do świadczeń, a w konsekwencji ułatwić zarządzanie systemem ze strony państwa (e-Zdrowie, 2018).

\section{Medycyna stylu życia}

\subsection{Aspekty teoretyczne}

Globalne Stowarzyszenie Medycyny Stylu Życia definiuje ten trend jako specjalizację medycyny opartą na dowodach, która używa metod terapeutycznych, bez wykorzystania leków, do zapobiegania, leczenia lub łagodzenia skutków chorób niezakaźnych (Lifestyle Medicine, 2018). Metody te dotyczą szeroko pojętego stylu życia i pogrupowane są według sześciu obszarów (Lifestyle Medicine, 2018):

1. zdrowego żywienia, w tym diety opartej na produktach roślinnych;

2. regularnej aktywności fizycznej;

3. odpowiedniego snu;

4. zarządzania stresem, unikania ryzyka;

5. ograniczenia używania tytoniu lub innych substancji szkodliwych;

6. relacji społecznych, ich tworzenia i podtrzymywania.

Po raz pierwszy sformułowanie „medycyna stylu życia” zostało wykorzystane do nazwy sympozjum w roku 1989, a w następnym został opublikowany pierwszy artykuł o takim brzmieniu (Yeh, Kong, 2013,2). Definicja sformułowana przez Rippe'ego w końcu XX wieku zakłada, że medycyna stylu życia to integrowanie szeroko pojętej współczesnej medycyny z praktykami zdrowego stylu życia. Według tej definicji całościowe podejście skuteczniej zapobiega powstawaniu i rozwojowi chorób cywilizacyjnych w ich początkowych okresach, a w przypadku stwierdzenia danego schorzenia służy jako uzupełnienie terapii tradycyjnej opartej na środkach leczniczych. Książka Lifestyle Medicine autorstwa Rippe'ego została uznana za pierwszą przełomową publikację w dziedzinie medycyny stylu życia (Rippe, 1999). Najnowsze, z 2019 roku, trzecie wydanie książki pod tym samym tytułem pod redakcją Rippe, prezentuje zaktualizowane zagadnienia i do- 
starcza cennych informacji nie tylko pracownikom służby zdrowia, ale wszystkim zainteresowanym, z dziedziny żywienia, fizjologii ćwiczeń, psychologii, medycyny behawioralnej, promocji zdrowia i polityki publicznej, w której zasady medycyny stylu życia odgrywają coraz większą rolę (Rippe, 2019).

Kolejne spojrzenie na tę nową dziedzinę medyczną prezentują Egger, Binns i Rossner, którzy definiują medycynę stylu życia jako „zastosowanie zasad środowiskowych, behawioralnych, medycznych i motywacyjnych do zarządzania problemami zdrowotnymi związanymi ze stylem życia w warunkach klinicznych" (Egger, Binns, Rossner, 2007, 1). W nowym wydaniu swojej książki z 2011 roku autorzy poszerzają definicję, dodając aspekt samozarządzania, który jest konieczny do właściwej terapii chorób przewlekłych (Egger, Binns, Rossner, 2011).

Idea medycyny stylu życia zakłada dogłębną analizę codziennych zachowań i nawyków pacjenta, opracowanie spersonalizowanych programów leczenia oraz ich realizację na poziomie indywidualnym, grupowym czy też społecznym. Działania te wspomagają utrwalenie zmian opartych na zdrowym stylu życia, co skutkuje zmianami w systemie zdrowotnym. To nowe podejście w medycynie opiera się na badaniu przyczyn powstania chorób, a nie tylko na leczeniu ich symptomów (Hyman, Ornish, Roizen, 2009).

Medycyna stylu życia jest definiowana na różne sposoby, zmieniające się z biegiem czasu, jednak punktem wspólnym każdego z określeń jest zdrowy styl życia i jego szczególne znaczenie w leczeniu chorób cywilizacyjnych oraz zapobieganiu ich powstawania i rozwoju (Yeh, Kong, 2013). U podstaw medycyny stylu życia stoi pacjent, który, dbając o własne zdrowie, zapobiega epidemii chorób cywilizacyjnych, rozwijających się na skutek niewłaściwego stylu życia. Medycyna stylu życia wywiera wpływ jednocześnie na kilkanaście czynników zdrowia, tworząc podstawę do prewencji, leczenia oraz wspomagania leczenia farmakologicznego. W nowym modelu istotą jest podejście holistyczne i partnerskie, którego podstawą jest edukacja $\mathrm{z}$ zastosowaniem środków motywujących pacjenta w celu osiągnięcia przez niego zdrowia (SKN, 2019). Dlatego edukacja medyczna w zakresie medycyny stylu życia jest niezbędna, aby umożliwić wszystkim pracownikom opieki zdrowotnej nauczanie skutecznego doradzania pacjentom w zakresie zachowań prozdrowotnych (Polak, Pojednic, Phillips, 2015).

Wyniki badań epidemiologicznych wskazują, iż obecny model medycyny jest efektywny dla krajów trzeciego świata, gdzie wciąż dominują choroby zakaźne oraz niedożywienie wynikające z ubóstwa jako główne czynniki umieralności. Dla krajów rozwiniętych natomiast, w których głównym powodem problemów zdrowotnych jest nieprawidłowy styl życia, ten model medycyny traci na wartości. Wobec tego powstaje zapotrzebowanie na nowe podejście do formułowania strategii współczesnej medycyny (Śliż, 2019).

Medycyna stylu życia jako dziedzina medycyny swój rozwój w Polsce rozpoczęła stosunkowo niedawno. Pierwszy podręcznik o nazwie Medycyna stylu życia został wydany w 2018 roku. Wydanie to, będące dużym zbiorem wiedzy 
specjalistycznej na temat medycyny stylu życia, skierowane jest nie tylko do specjalistów z obszaru zdrowia. W dużej mierze książka jest przeznaczona do szerokiego stosowania, dzięki czemu może stanowić skuteczne narzędzie do hamowania rozwoju chorób cywilizacyjnych (Śliż, Mamcarz, 2018). Rok 2018 odznaczył się również powstaniem Polskiego Towarzystwa Medycyny Stylu Życia, które w roku 2019 zorganizowało I Międzynarodowy Kongres Medycyny Stylu Życia (Polskie Towarzystwo, 2019).

\subsection{Optymalizacja w leczeniu pacjenta - EBM}

EBM to akronim pojęcia Evidence-based medicine, co w języku polskim brzmi jako medycyna oparta na dowodach czy też medycyna oparta na faktach. Ze względu na niedokładność thumaczenia Polski Instytut Evidence Based Medicine przyjął założenie posługiwania się oryginalną nazwą pojęcia, które po raz pierwszy zostało wykorzystane przez kanadyjskiego profesora medycyny i epidemiologii klinicznej Gordona Guyatta w roku 1991. Ważnym elementem w definicji EBM są wartościowe dane uzyskane z licznych badań klinicznych (Co to jest EBM, 2019).

Dane oparte na badaniach EBM wyróżniają się swoją wiarygodnością i tworzą „złoty standard” podejmowania decyzji klinicznych. Ze względu na dużą liczbę nowych informacji dotyczących badań medycznych oraz problem z identyfikacją wartościowych treści powstała konieczność sporządzenia podsumowujących dokumentów, które obecnie są opracowywane przez międzynarodową organizację non profit Cochrane Collaboration (Koperny et al., 2016).

Metoda EBM pozwala na analizę opublikowanych oraz nieupowszechnionych wyników dla zastosowania ich w medycynie praktycznej. Interpretacje tego typu są sformalizowane w postaci dokumentacji medycznej, która opracowywana jest przez grono specjalistów z różnych krajów świata. W latach dziewięćdziesiątych ubiegłego wieku powstały ośrodki naukowe Cochrane Collaboration mające na celu recenzowanie publikacji w połączeniu z wynikami badań praktycznych. Publikacja przeglądu systematycznego jest procesem skomplikowanym, polegającym na zgłoszeniu tematu nowego badania oraz opracowaniu protokołu analiz, który jest poddany ocenie przez zewnętrznych recenzentów. Ważnymi etapami w tworzeniu przeglądu są: sformułowanie pytania klinicznego, wyszukiwanie i kwalifikacja badań oraz ekstrakcja danych, ocena ich wiarygodności oraz wyników końcowych. Istotnym aspektem jest zobowiązanie się autorów do aktualizacji zaproponowanych do publikacji przeglądów (Mauer-Górska, 2007, 262).

Jednym z założeń medycyny opartej na faktach jest ciągłe poszukiwanie i uaktualnianie wiedzy na temat wiarygodnych danych uzyskanych w badaniach naukowych oraz koncentrowanie się na rozwiązaniach skutecznych oraz uzasadnionych kosztowo. W wyniku zastosowania medycyny opartej na faktach specjalista poszerza własną perspektywę, stwarzając możliwości na rzecz innowacji 
praktyk lekarskich, opierając się na wiarygodnych danych. Ważnym elementem jest włączenie pacjenta w proces decyzyjny, w którym istnieje możliwość odrzucenia proponowanych metod leczenia i wyboru właściwej (Gotlib et al., 2014, 3).

Evidence-based medicine opiera się na połączeniu indywidualnych doświadczeń z obserwacjami konkretnego specjalisty. Ważną częścią EBM są badania laboratoryjne, które dostarczają 60-70\% wiedzy na temat aktualnego stanu zdrowia pacjenta. Stanowi to podstawę do podjęcia decyzji klinicznych, trafność których zależy również od ciągłego zdobywania aktualnych informacji. Obszar ten zdefiniowano jako przegląd systematyczny, który zawiera w sobie analizę badań dowodów medycznych oraz metaanalizę, czyli statystyczne przeglądy wyników badań (Owczarek, Nakaczewska, Paliszewska, 2009, 247-248).

EBM jako dziedzina medycyny niesie korzyści kliniczne i ekonomiczne, istotne zarówno dla pacjenta, jak i systemu ochrony zdrowia. W sytuacji ograniczonych zasobów ludzkich i finansowych oraz dużych nakładów na leczenie pacjentów korzyści ze stosowania EBM są zauważalne i doceniane. Przykładem ekonomicznych korzyści jest zastępowanie tradycyjnych metod analizy sytuacji zdrowotnej szybkimi testami, co obniża koszty nawet do $20 \%$. Dostępność informacji o nowych dowodach zwiększa skuteczność wyboru odpowiedniego sposobu przez przedstawienie szerokich możliwości leczniczych. Szybka diagnoza i analiza optymalnego sposobu leczenia jest kolejną mocną stroną, w której ważną rolę odgrywa medycyna laboratoryjna (Owczarek, Nakaczewska, Paliszewska, 2009, 249-250).

Standardy EBM służą też do opracowania koszyka świadczeń gwarantowanych w opiece medycznej. Dzięki EBM jest możliwość doboru gwarantowanych procedur, które są najbardziej skuteczne i odpowiednie, zarówno dla systemu zdrowotnego, jak i dla pacjentów. Rozwój medycyny opartej na faktach skutkował rozbudową analiz typu Health Impact Assessment (HIA) (Golinowska, 2015, 327). HIA jest sposobem oceny skutków zdrowotnych planów i projektów w różnych sektorach gospodarki przy użyciu metod ilościowych i jakościowych (Health, 2020).

Podsumowując, metodologia EBM jest podstawą wytycznych dla lekarzy i innych profesjonalistów medycznych oraz raportów HTA (raportów oceny technologii zdrowotnych) dla decydentów (Dobska, 2018, 120). Pozwala ona na (Szajewska, 2011):

1. odróżnianie informacji bardziej od mniej wiarygodnych;

2. wyłowienie informacji przydatnych klinicznie, czyli istotnych dla pacjentów;

3. zrozumienie języka badań klinicznych i publikacji medycznych;

4. zrozumiałe i proste przekazanie informacji pacjentom;

5. uniezależnienie lekarzy.

W kontekście optymalizacji procesu leczenia pacjenta prawidłowe rozumienie koncepcji EBM wymaga od lekarza rozpoznania sytuacji klinicznej, znajomości danych naukowych oraz zrozumienia pacjenta przez pryzmat jego emocji, uwarunko- 
wań rodzinnych, kulturowych czy finansowych (Gajewski, Jaeschke, Mrukowicz, 2003, 33).

\section{Styl życia polskich konsumentów w świetle wyników badania własnego}

\subsection{Metodyka badania}

W okresie grudzień 2019-marzec 2020 roku przeprowadzono w internecie badanie własne skierowane do pełnoletnich mieszkańców Polski. Celem badania było zdobycie informacji o stylu życia i zachowaniach prozdrowotnych konsumentów w kontekście ich znajomości nowej dziedziny medycyny — medycyny stylu życia. Zastosowano metody doboru nielosowego - nieprobabilistycznego. Po pierwsze, zastosowano dobór celowo-losowy na zasadzie kuli śniegowej, umieszczając link do badania w serwisach społecznościowych: Facebook, LinkedIn, GoldenLine. Po drugie, zastosowano dobór celowy, wysyłając mailing z linkiem do badania do znajomych autorów opracowania. Wreszcie, zastosowano ankietę audytoryjną, w której respondentami byli studenci studiów stacjonarnych i niestacjonarnych dwunastu grup administracyjnych, a badanie odbyło się w salach laboratoryjnych i ćwiczeniowych na terenie Uniwersytetu Ekonomicznego we Wrocławiu. Studenci zostali poinformowani o celu badania i sposobie wypełniania kwestionariusza. W odróżnieniu od wcześniejszych sposobów dotarcia do respondentów w wypadku ankiety audytoryjnej uzyskano stuprocentową zwrotność materiału (prowadzący zajęcia, jeden z autorów opracowania, pilnował, aby wszyscy wzięli udział w badaniu).

Ze względu na zastosowane techniki badawcze i sposoby dotarcia do respondentów próba badawcza nie miała charakteru reprezentatywnego, a uzyskane wyniki obrazowały jedynie zastany stan rzeczy i nie mogły być odzwierciedleniem opinii całej populacji. Pozwoliły jednak dokonać ogólnej diagnozy i poznać pewne tendencje.

\subsection{Analiza i interpretacja wyników}

W ankietyzacji wzięło udział 415 respondentów, w tym trzy osoby były niepełnoletnie i w wyniku pytania filtrującego nie przeszły do kolejnego etapu. Struktura respondentów według płci była następująca: 310 kobiet (co stanowiło 75,2\%), 99 mężczyzn (24\%) oraz trzy wskazania ,inne”- 0,8\%. Średni wiek ankietowanego wynosił 26,92 lat z odchyleniem standardowym na poziomie 10,1 lat, co oznaczało, że wiek respondenta różnił się od średniego wieku przeciętnie o 10,1 lat. Zróżnicowanie wieku mierzone współczynnikiem zmienności było na poziomie $37,51 \%$, co wskazywało, że wiek był istotny statystycznie (Vs $>10 \%$ ). 
Połowa respondentów była w wieku 22,5 roku (mediana). 25\% ankietowanych miała nie więcej niż 20 lat, a pozostałe $75 \%$ ankietowanych miała co najmniej 20 lat (kwartyl pierwszy). W wieku co najwyżej 30 lat było 75\% ankietowanych, a pozostałe $25 \%$ ankietowanych miało 30 lat lub więcej (kwartyl trzeci). Najczęstszym wiekiem było 20 lat (dominanta). Najmłodsi respondenci mieli po 18 lat (kobiety i mężczyźni), a najstarsi 70 lat (mężczyźni).

Niespełna $20 \%$ respondentów spotkało się już z pojęciem „medycyna stylu życia", co może potwierdzać fakt, iż ta dziedzina medycyny dopiero raczkuje w naszym kraju i zaczyna się o niej mówić szerzej od I Międzynarodowego Kongresu Medycyny Stylu Życia zorganizowanego w 2019 roku. Poproszono wszystkich ankietowanych o wyjaśnienie pojęcia „medycyny stylu życia”. Ze względu na dużą różnorodność odpowiedzi wszystkie określenia pogrupowano w dziesięć kategorii, co zobrazowano w tabeli 2.

Tabela 2. Pojęcie ,medycyna stylu życia” w opinii ankietowanych

\begin{tabular}{|l|r|c|}
\hline \multicolumn{1}{|c|}{ Kategoria } & $\begin{array}{c}\text { Liczba } \\
\text { odpowiedzi }\end{array}$ & Udział \% \\
\hline Nie wiem & 41 & 10,0 \\
\hline Zdrowy styl życia & 257 & 62,4 \\
\hline Dbanie o zdrowie w oparciu o badania naukowe & 9 & 2,2 \\
\hline Profilaktyka chorób cywilizacyjnych & 21 & 5,1 \\
\hline Leczenie konsekwencji stylu życia & 4 & 1,0 \\
\hline Holistyczne ujęcie zdrowia & 38 & 9,2 \\
\hline Ekologiczne podejście do zdrowia & 2 & 0,5 \\
\hline Alternatywa dla medycyny konwencjonalnej & 18 & 4,4 \\
\hline Dobieranie indywidualnych programów profilaktyki i leczenia & 9 & 2,2 \\
\hline $\begin{array}{l}\text { Nauka interdyscyplinarna pozwalająca na zachowanie równo- } \\
\text { wagi w życiu }\end{array}$ & 13 & 3,2 \\
\hline
\end{tabular}

Źródło: badania własne.

Najwięcej respondentów utożsamia pojęcie „medycyna stylu życia” ze zdrowym stylem życia. Jak scharakteryzować to pojęcie, nie wiedziało $10 \%$ ankietowanych. Holistyczne ujęcie zdrowia, profilaktyka chorób cywilizacyjnych i alternatywa dla medycyny konwencjonalnej - to następne w kolejności wskazania respondentów określające medycynę stylu życia. Wskazania respondentów świadczą o dość dobrym rozumieniu medycyny stylu życia.

W kolejnym kroku badani mieli wskazać prawidłowe, według nich, określenia „,medycyny stylu życia”. Do wyboru były cztery definicje ${ }^{1}$ i można było zaznaczyć co najmniej jedną, przy czym ostatnia definicja została wymyślona przez

1 Trzy pierwsze definicje zostały ujęte w rozdziale trzecim niniejszego opracowania. 
autorów badania i nie jest właściwym opisem medycyny stylu życia. Rozkład wskazań definicji „medycyny stylu życia” zaprezentowano w tabeli 3.

Tabela 3. Definicje „medycyny stylu życia” we wskazaniach respondentów

\begin{tabular}{|l|c|c|}
\hline \multicolumn{1}{|c|}{ Definicja } & $\begin{array}{c}\text { Liczba } \\
\text { wskazań }\end{array}$ & Udział \% \\
\hline $\begin{array}{l}\text { Integrowanie szeroko pojętej współczesnej medycyny z prakty- } \\
\text { kami zdrowego stylu życia }\end{array}$ & 270 & 65,5 \\
\hline $\begin{array}{l}\text { Zastosowanie zasad środowiskowych, behawioralnych, medycz- } \\
\text { nych i motywacyjnych do zarządzania problemami zdrowotny- } \\
\text { mi związanymi ze stylem życia w warunkach klinicznych }\end{array}$ & 128 & 31,1 \\
\hline $\begin{array}{l}\text { Specjalizacja medycyny oparta na dowodach, która używa } \\
\text { metod terapeutycznych, bez wykorzystania leków, do zapobie- } \\
\text { gania, leczenia lub łagodzenia skutków chorób niezakaźnych }\end{array}$ & 95 & 23,1 \\
\hline $\begin{array}{l}\text { Dziedzina medycyny zajmująca się testowaniem nowych metod } \\
\text { terapeutycznych związanych ze stylem życia }\end{array}$ & 107 & 26,0 \\
\hline
\end{tabular}

Źródło: badania własne.

Najwięcej wskazań otrzymała pierwsza definicja, z którą identyfikuje się $65,5 \%$ respondentów. Z kolei definicja sformułowana przez autorów niniejszego opracowania uplasowała się na przedostatnim miejscu, co może oznaczać, że wydała się mało wiarygodna i wskazywać na dość dobrą świadomość ankietowanych.

Medycyna oparta na faktach, dowodach to polskie tłumaczenia akronimu EBM, o którym była mowa w rozdziale czwartym opracowania. Okazuje się, że blisko $89 \%$ respondentów nie wiedziało, co oznacza ten skrótowiec. W pozostałych, prawidłowych odpowiedziach, albo padały określenia „Medycyna oparta na dowodach/faktach” albo „Evidence Based Medicine”. Oto kilka innych wybranych thumaczeń:

— „Evidence Balance Medicine”;

— „Edukacja Behawioralno-Medyczna”;

— „Evidence Based Method”;

— „Evidens Beasted Medicin”.

Podobnie jak w wypadku definicji „medycyny stylu życia” w kolejnym pytaniu respondenci proszeni byli o wskazanie prawidłowego tłumaczenia skrótowca EBM na język polski. Do wyboru były cztery odpowiedzi, w tym dwie zostały wymyślone przez autorów opracowania. Na wykresie 1 przedstawiono zestawienie tłumaczeń akronimu EBM z liczbą wskazań. Wymyślone określenia zaznaczono ciemniejszym kolorem.

Najwięcej wskazań padło na wymyślone tłumaczenie EBM — „Ewidencję Badań Medycznych". Po przeanalizowaniu wszystkich odpowiedzi respondentów okazało się, że na to thumaczenie wskazywały osoby, które nie podały swojego rozwinięcia akronimu, zaznaczając opcję „nie wiem”. Wybór „medycyny opartej 


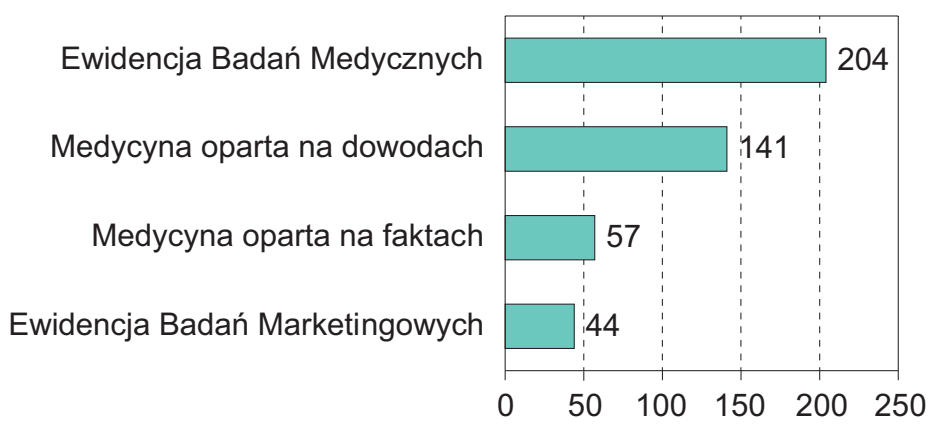

Wykres 1. Tłumaczenia akronimu EBM w opinii ankietowanych

Źródło: badania własne.

na dowodach" jako drugi w kolejności liczby wskazań potwierdza słuszny kierunek myślenia respondentów.

Wyniki kolejnego pytania miały wyłonić wizerunek współczesnego konsumenta. Ankietowani zostali poproszeni o wybranie określeń pasujących do nich. W tabeli 4 zaprezentowano określenia zaproponowane przez autorów opracowania i wskazania respondentów, uporządkowane malejąco.

Tabela 4. Charakterystyka współczesnego konsumenta

\begin{tabular}{|l|c|c|}
\hline \multicolumn{1}{|c|}{ Określenia/działania } & $\begin{array}{c}\text { Liczba } \\
\text { wskazań }\end{array}$ & Udział \% \\
\hline $\begin{array}{l}\text { Jestem świadomym konsumentem (czytam etykiety na opako- } \\
\text { waniach) }\end{array}$ & 300 & 72,8 \\
\hline Dbam o swoje zdrowie, regularnie uprawiając sport & 163 & 39,6 \\
\hline $\begin{array}{l}\text { Dbam o swoje zdrowie, jedząc prawidłowo zbilansowane } \\
\text { posiłki }\end{array}$ & 147 & 35,7 \\
\hline Uwielbiam kawę i mogę ją pić na okrągło & 137 & 33,3 \\
\hline $\begin{array}{l}\text { Często kupuję impulsywnie (pod wpływem chwili/akcji promo- } \\
\text { cyjnych) }\end{array}$ & 119 & 28,9 \\
\hline Śpię co najmniej 8 godzin w nocy & 118 & 28,6 \\
\hline Codziennie przyjmuję suplementy jako uzupełnienie diety & 111 & 26,9 \\
\hline Badam się regularnie & 104 & 25,2 \\
\hline $\begin{array}{l}\text { Każdy zakup rozważam wcześniej bardzo dokładnie, nie zosta- } \\
\text { wiam nic przypadkowi }\end{array}$ & 104 & 25,2 \\
\hline Nie piję w ogóle kawy & 101 & 24,5 \\
\hline Często sięgam po używki (papierosy, alkohol, inne) & 69 & 16,7 \\
\hline Często jadam w restauracjach typu fast-food & 63 & 15,3 \\
\hline Nabywam wyłącznie zdrowe produkty żywieniowe & 51 & 14,8 \\
\hline Wszystkie posiłki przygotowuję sam/-a & 52 & 12,6 \\
\hline
\end{tabular}

Źródło: badania własne.

Ekonomia - Wroclaw Economic Review 26/3, 2020

(C) for this edition by CNS 
Na podstawie wyników tabeli 4 wyłania się obraz współczesnego konsumenta. Z deklaracji respondentów można wnioskować, iż prowadzą zdrowy styl życia, regularnie uprawiając sport, jedząc prawidłowo zbilansowane posiłki. Będąc świadomym konsumentem, czytają etykiety na opakowaniach i rozważają każdy zakup bardzo dokładnie. Na piątym miejscu uplasowało się określenie „Często kupuję impulsywnie (pod wpływem chwili/akcji promocyjnych)”. Może to oznaczać, że respondenci są podatni na reklamę i inne narzędzia marketingowe i są tego świadomi. Na ostatni miejscu ulokowało się samodzielne przygotowywanie wszystkich posiłków, co w zasadzie nie powinno dziwić w kontekście średniego (26,92 lat), a nawet najczęstszego (20 lat) wieku respondentów. Jest to okres studiowania i podejmowania pierwszej pracy przez młode osoby, stąd jest mało czasu na regularne gotowanie $\mathrm{w}$ domu.

Kolejne pytanie $\mathrm{z}$ kategorii używki dotyczyło kwestii palenia papierosów (lub e-papierosów). Z deklaracji respondentów wynika, że blisko $80 \%$ z nich nie pali, a 12,6\% ankietowanych planuje rzucić ten nałóg. Są też badani, którzy palą i nie zamierzają rzucić (7,5\%). Wśród palaczy mniej niż paczkę papierosów dziennie deklaruje 73,5\%. Dość spora grupa (20,5\%) jest tak zwanym palaczem hybrydowym, czyli sięga zarówno po papierosy, jak i e-papierosy. Pocieszające jest, że palenie co najmniej paczki papierosów dziennie deklaruje zaledwie $6 \%$ ankietowanych.

Stres w życiu człowieka jest nieodzowny, w związku z czym kolejne pytanie dotyczyło właśnie tego zjawiska. Rozkład częstotliwości stresowania się wśród ankietowanych zaprezentowano na diagramie 1 .

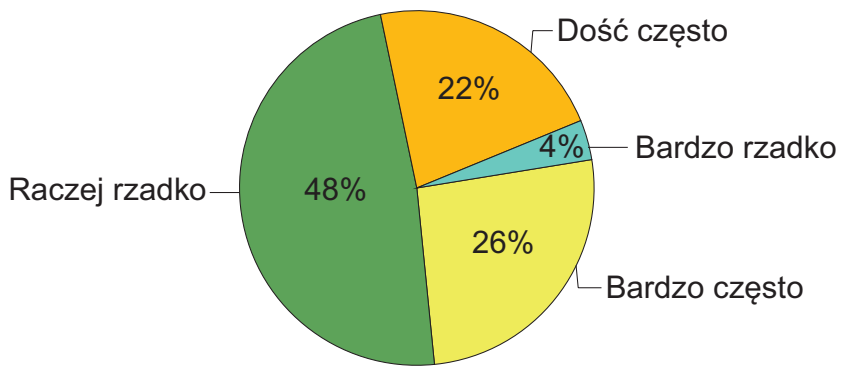

Diagram 1. Rozkład odpowiedzi na pytanie: „Jak często Pan/Pani się stresuje?”

Źródło: badania własne.

Wyniki odpowiedzi ankietowanych nie są zaskoczeniem, gdyż, biorąc pod uwagę nie tylko młode osoby, każdy z nas doświadcza codziennie pewnej dawki stresu, a w kontekście medycyny stylu życia trzeba popracować nad niwelowaniem tego stanu.

Kolejne pytanie związane było ze znajomością pojęcia „prosument”. Blisko $61 \%$ respondentów nie zna tego pojęcia, a 26,5\% kiedyś słyszało, ale nie pamięta, co ona oznacza. Dla grupy 52 osób, które znają to pojęcie bardzo dobrze i podały 
własne jego znaczenie, sformułowano kilka kategorii odpowiedzi, do których przydzielono określenia ankietowanych. W tabeli 5 przedstawiono kategorie wraz z przyporządkowanymi do nich odpowiedziami respondentów.

Tabela 5. Pojęcie ,prosumenta” w opinii ankietowanych

\begin{tabular}{|l|c|c|}
\hline \multicolumn{1}{|c|}{ Kategoria } & $\begin{array}{c}\text { Liczba } \\
\text { odpowiedzi }\end{array}$ & Udział \% \\
\hline $\begin{array}{l}\text { Konsument biorący udział w projektowaniu/tworzeniu produk- } \\
\text { tu i/lub jego promowaniu }\end{array}$ & 23 & 44,2 \\
\hline Konsument zaangażowany, świadomy, aktywny & 15 & 28,8 \\
\hline Połączenie konsumenta z producentem & 12 & 23,1 \\
\hline Wytwarzający energię na własne potrzeby & 2 & 3,9 \\
\hline
\end{tabular}

Źródło: badania własne.

Według większości badanych prosument jest konsumentem zaangażowanym we współtworzenie produktu, biorącym udział w jego promowaniu. To współczesny konsument świadomie i aktywnie dokonujący wyborów. Ankietowani wskazali także na pochodzenie słowa ,prosument” jako połączenie słów i funkcji konsumenta $\mathrm{z}$ producentem.

\section{Wnioski}

Medycyna stylu życia jako innowacyjne podejście do zdrowia traktuje współczesnego konsumenta w sposób holistyczny. Ten prozdrowotny trend zakłada całościowe ujęcie różnych sfer działania człowieka i opiera się na założeniu ich wzajemnego wpływu na siebie. Ale czy dzisiejszy konsument rzeczywiście jest prosumentem, świadomie, odpowiedzialnie i kompleksowo traktującym swoje zdrowie? Odpowiedzi na to pytanie miały udzielić wyniki autorskiego badania internetowego skierowanego do osób pełnoletnich z terenu całej Polski.

Analiza stylu życia polskich konsumentów na podstawie wyników badania własnego pokazuje, że tylko niespełna $20 \%$ respondentów zna pojęcie „medycyna stylu życia". Jest ono przez większość ankietowanych utożsamiane ze zdrowym stylem życia. Inne określenia, według respondentów, to holistyczne ujęcie zdrowia, profilaktyka chorób cywilizacyjnych, alternatywa dla medycyny konwencjonalnej.

Z deklaracji respondentów wynika, iż współczesny konsument prowadzi zdrowy styl życia, regularnie uprawiając sport, jedząc prawidłowo zbilansowane posiłki. Będąc świadomym konsumentem, czyta etykiety na opakowaniach i rozważa każdy zakup bardzo dokładnie. Jest jednocześnie podatny na reklamę i inne narzędzia marketingowe i jest tego świadomy. 
Blisko 61\% respondentów nie zna pojęcia ,prosument”. Dla pozostałych osób jest nim współczesny konsument świadomie i aktywnie dokonujący wyborów, zaangażowany we współtworzenie produktu i biorący udział w jego promowaniu. Ankietowani wskazali także na tłumaczenie nazwy „prosument” jako połączenia słów „,producent” i „,konsument”.

Analiza wyników badania własnego pozwoliła zorientować się w nawykach zdrowotnych respondentów, co, z uwagi na brak reprezentatywności próby, nie może być odniesione do ogółu populacji. Należy to traktować jako stan zastany, co nie umniejsza jednak wartości badania, albowiem intencją autorów było zebranie wstępnych informacji na temat zachowań prozdrowotnych internautów. Wyniki badania ankietowego prezentowane w tym opracowaniu mogą stanowić, zdaniem autorów, przyczynek do dalszych badań konsumentów w kontekście stylu ich życia i dbałości o własne zdrowie.

\section{Bibliografia}

Aleksandrowicz, I.M. (2019). Noworoczne zmiany w prawie. OSOZ, 12, 49.

Co to jest EBM. Polski Instytut Evidence Based Medicine. Data dostępu: 10.12.2019, http://ebm. org.pl/show.php?aid=15267.

Cyfryzacja. Zostań kapitanem zmian (2019). OSOZ, 12, 31-36.

Czapiński, J. (2019). Świadomość Polaków w zakresie strategicznych wyzwań stojących przed Polską oraz chęć wykorzystania nowych technologii do ich rozwiązania. W Fundacja Digital Poland. Raport: Technologia w stużbie społeczeństwu. Czy Polacy zostana spoleczeństwem 5.0? Warszawa.

Czerska, I. (2016). Relacje lekarz-pacjent a wybrane teoretyczne modele relacji w kontekście dehumanizacji medycyny. Handel Wewnętrzny, 5(364), 37-45.

Dobska, M. (2018). Interpretacja jakości w usługach medycznych. W M. Dobska (red.), Zarządzanie podmiotem leczniczym. Warszawa: PZWL Wydawnictwo Lekarskie.

Egger, G., Binns, A., Rossner, S. (2007). Introduction to lifestyle medicine. W G. Egger, A. Binns, S. Rossner (eds). Lifestyle medicine. Sydney: McGraw-Hill Australia Pty Ltd.

Egger, G., Binns, A., Rossner, S. (2011). Lifestyle medicine: managing diseases of lifestyle in the 21 st century. Sydney, North Ryde: McGraw-Hill.

e-Zdrowie, czyli pacjent w centrum rewolucji (2018). Fundacja Digital Poland. Data dostępu: 16.02.2020, https://businessinsider.com.pl/technologie/digital-poland/sluzba-zdrowia-a-transformacja-cyfrowa/2lckkgb?fbclid=IwAR3QcF5LM116_5xXouzzh_Nu64k1XcNor5FNqX-11OYTzQQwbwGeVzw7HFs.

Fundacja Digital Poland (2019). Raport: Technologia w stużbie społeczeństwu. Czy Polacy zostana społeczeństwem 5.0? Warszawa.

Gajewski, P., Jaeschke, R., Mrukowicz, J. (2003). Evidence based medicine (EBM) współczesną sztuką lekarską. Cele Polskiego Instytutu Evidence Based Medicine. Medycyna Praktyczna, 3, 31-34.

Gogola, P. (2019). E-zdrowie? Jak wybrać oprogramowanie dla lekarza, przychodni czy szpitala? OSOZ, 12, 76-78.

Golinowska, S. (2015). Od ekonomii do ekonomiki zdrowia. Warszawa: Wydawnictwo PWN.

Gotlib, J., Belowska, J., Panczyk, M., Dykowska, G., Wójcik, G. (2014). Evidence-based Medicine i Evidence-based Nursing Practice — przegląd polskiego piśmiennictwa naukowego. Problemy Pielegniarstwa, 2(22), 1-5.

Ekonomia - Wroclaw Economic Review 26/3, 2020

(C) for this edition by CNS 
Health Impact Assessment (HIA) (2020). World Health Organization. Data dostępu: 14.03.2020, https://www.who.int/hia/en/.

Hyman, M.A., Ornish, D., Roizen, M. (2009). Lifestyle Medicine: Treating the Causes of Disease. Alternative Therapies, 6(15), 12-14.

Innowacje ochrony zdrowia 2020 (2019). OSOZ, 12, 41

Kautsch, M. (red.) (2010). Zarzadzanie w opiece zdrowotnej. Nowe wyzwania. Warszawa: Oficyna a Wolters Kluwer business.

Koperny, M., Leśniak, W., Jankowski, M., Bała, M. (2016). Cochrane collaboration — rola w rozwoju medycyny opartej na wiarygodnych i aktualnych publikacjach oraz możliwości współpracy w Polsce. Przeglad Epidemiologiczny, 70(3), 508-520.

Krzepicka, A. (2016). Współczesny konsument — konsument digitalny. Studia Ekonomiczne. Zeszyty Naukowe Uniwersytetu Ekonomicznego w Katowicach, 255, 207-214.

Lifestyle Medicine (2018). American College of Lifestyle Medicine. Data dostępu: 20.10.2019, https://lifestylemedicineglobal.org/lifestyle-medicine/.

Łukowski, B., Jankowiak-Bolko, B., Staszewski, R., Samborski, W., Mojs, E. (2018). Wartość dla pacjenta - budowa strategii optymalizacji terapii chorób reumatycznych z perspektywy pacjenta, lekarza i firmy farmaceutycznej. Forum Reumatologiczne, 4(4), 231-237.

Mauer-Górska, B. (2007). Evidence-based: nowa metoda analityczno-syntetycznego opracowania publikacji naukowych. Przeglad Biblioteczny, 75, 2, 261-270.

Nowak-Starz, G., Siwek, M., Salwa, A., Babiarz, A., Bujanowska, M., Strzelecka, A., Wójcik, T., Markowski, K. (2018). Rola jakości usług medycznych we współczesnym systemie ochrony zdrowia. W R. Asienkiewicz, K. Markocka-Mączka, M. Biskup (red.). Zdrowie publiczne standardem dobrostanu. Lublin: Wydawnictwo Naukowe NeuroCentrum, 237-247.

O cyfrowej transformacji polskiej służby zdrowia podczas Forum e-Zdrowia (2018). Puls Medycyny. Data dostępu: 15.02.2020, https://pulsmedycyny.pl/o-cyfrowej-transformacji-polskiej-sluzby-zdrowia-podczas-forum-e-zdrowia-2018-940620?fbclid=IwAR10JjIhVfzgqWYpZE wNesWqVdqD5tqwtLyWaO_0Ec78fQaVmZrCwFGQJs4.

Owczarek, H., Nahaczewska, W., Paliszkiewicz, A. (2009). Badania diagnostyczne w medycynie laboratoryjnej opartej na dowodach naukowych. Diagnostyka Laboratoryjna, 45, 3, 247-251.

Pacjent w centrum systemu opieki zdrowotnej — transformacja cyfrowa sektora (2019). Medexpress. Data dostępu: 15.02.2020, https://www.medexpress.pl/pacjent-w-centrum-systemu-opieki-zdrowotnej-transformacja-cyfrowa-sektora/74027.

Polak, R., Pojednic, R.M., Phillips, E.M. (2015). Lifestyle Medicine Education. American Journal of Lifestyle Medicine, 9(5), 361-367.

Polskie Towarzystwo Medycyny Stylu Życia (2019). Data dostępu: 8.12.2019, https://ptmsz.pl/.

Prosument (2019). Wikipedia. Data dostępu: 15.02.2020, https://pl.wikipedia.org/wiki/Prosument.

Rippe, J.M. (1999). Lifestyle Medicine. Malden, Mass.: Blackwell Science.

Rippe, J.M. (2019). Lifestyle Medicine. Boca Raton, FL: CRC Press.

SKN Medycyny Stylu Życia WUM (2019). Data dostępu: 17.10.2019, https://m.facebook.com/notes/skn-medycyny-stylu-\%C5\%BCycia-wum/o-nas/594457607657231/.

Szajewska, H. (2011). Podstawy EBM, czyli medycyny opartej na danych naukowych. II Katedra Pediatrii Warszawskiego Uniwersytetu Medycznego. Data dostępu: 14.03.2020, http://pediatria2.wum.edu.pl/sites/pediatria2.wum.edu.pl/files/ebm_studenci_2011.pdf.

Śliż, D., Czym jest medycyna stylu życia? Data dostępu: 13.11.2019, https://modanazdrowie.wum. edu.pl/sites/modanazdrowie.wum.edu.pl/files/czym_jest_medycyna_stylu_zycia_daniel_sliz. pdf.

Śliż, D., Mamcarz, A. (red.) (2018). Medycyna stylu życia. Warszawa: PZWL Wydawnictwo Lekarskie.

Technologie budowane w dobrej wierze (2019). OSOZ, 12, 59-62.

Toffler, A. (1980). The Third Wave. New York: William Collins Sons \& Co. Ltd.

Ekonomia - Wroclaw Economic Review 26/3, 2020

(C) for this edition by CNS 
Toffler, A. (1997). Trzecia fala. Warszawa: Państwowy Instytut Wydawniczy.

Yeh, B.I., Kong, I.D. (2013). The advent of lifestyle medicine. Journal of Lifestyle Medicine, 3(1), $1-8$. 